\title{
Collagen fingerprinting and the Chumash billfish fishery, Santa Barbara Channel, California, USA
}

\author{
Torben Rick $^{1}$ - Virginia L. Harvey ${ }^{2} \cdot$ Michael Buckley $^{2}$ (D) \\ Received: 23 December 2018 / Accepted: 27 August 2019/Published online: 21 November 2019 \\ (C) The Author(s) 2019
}

\begin{abstract}
Billfish from the families Xiphiidae (swordfish) and Istiophoridae (marlins and sailfish) are large, often pelagic fishes that are highly migratory. Although some billfish have been the target of global commercial and sport fisheries for decades, prehistoric billfish foraging is relatively rare, but includes systematic swordfish (Xiphias gladius) and/or striped marlin (Kajikia audax) exploitation in the Santa Barbara Channel region of California, the Gulf of Maine, and the northern coast of Chile. While whole vertebrae, rostra, and other elements can often be identified to species, fragments of these, or other non-diagnostic elements such as fin ray spines, as well as modified bones, are difficult to determine to species-level beyond general identification as billfish or "large fish." We performed collagen fingerprinting on modern $(n=17)$ and archaeological $(n=30)$ billfish and large tuna (Scombridae) remains from museum collections and Chumash archaeological sites in California's Santa Barbara Channel region to test this method for determining the species of fragmentary remains. These data demonstrate that collagen fingerprinting can distinguish between the families Istiophoridae, Xiphiidae, and Scombridae, although distinguishing between species within Istiophoridae needs additional research. All but one of our archaeological specimens are from swordfish, with just one striped marlin, suggesting that the Chumash were likely encountering or targeting swordfish more frequently than other billfish species. Our study demonstrates that collagen fingerprinting is an important technique for documenting ancient billfish and other fisheries around the world.
\end{abstract}

Keywords Collagen fingerprinting $\cdot$ Swordfish $\cdot$ Marlin $\cdot$ Tuna $\cdot$ Proteomics $\cdot$ Coastal archaeology $\cdot$ Historical ecology

\section{Introduction}

Swordfish and marlins (billfishes from the families Xiphiidae and Istiophoridae respectively) are among the largest bony fishes in the world's oceans today (Nakamura 1985; Shimose et al. 2010; Ellis 2013). They are generally pelagic and have

Electronic supplementary material The online version of this article (https://doi.org/10.1007/s12520-019-00930-4) contains supplementary material, which is available to authorized users.

Michael Buckley

m.buckley@manchester.ac.uk

Torben Rick

rickt@ si.edu

1 Department of Anthropology, National Museum of Natural History, Smithsonian Institution, Washington DC 20013-7012, USA

2 Department of Earth and Environmental Sciences, Manchester Institute of Biotechnology, University of Manchester, 131 Princess Street, Manchester M1 7DN, UK migrations that span thousands of kilometers. Because of their size and palatable flesh, billfishes have long been important for commercial and recreational fisheries in the Indo-Pacific, Atlantic, and Mediterranean, but many of these stocks have been greatly reduced (Nakamura 1985; Sjimose et al. 2010; Ellis 2013). Billfish are apex predators, play an important role in ocean food webs, and have long held cultural significance to coastal peoples around the world (Mather 1976; Nakamura 1980; Ellis 2013).

Despite their importance for commercial and recreational fisheries, systematic fishing for billfishes is relatively rare in the archaeological record, with some of the best-documented examples coming from the Santa Barbara Channel region of California, the Gulf of Maine, and the Chilean Atacama Desert Coast (Davenport et al. 1993; Bourque 2012; Sanger 2009; Spiess and Lewis 2001; Béarez et al. 2016). In addition to these areas, Béarez et al. (2016:190) noted archaeological swordfish or marlin bones in Mesolithic Denmark, the Neolithic French Mediterranean, Taiwan, the Marianas Islands, and Japan. Of the systematic prehistoric billfish 
fisheries in California, Maine, and Chile, all three appear to hold ritual significance, with billfish remains appearing in burials, in rock art, or as modified tools or artifacts (Davenport et al. 1993; Bernard 2004; Bourque 2012; Béarez et al. 2016; Lebow et al. 2016). The Chilean fishery for billfish includes some 98 striped marlin and 23 swordfish bones from the Zapatero site dated between 7400 and $5900 \mathrm{cal}$ BP (Béarez et al. 2016). In the Gulf of Maine, several sites have produced swordfish bones, including a number of occurrences in burial contexts with a primary temporal distribution between about 5000 and 3800 years ago (Spiess and Lewis 2001; Sanger 2009; Bourque 2012). In the Santa Barbara Channel Region, the vast majority of billfish bones occur after $1500 \mathrm{cal}$ BP and may be associated with the appearance of the plank canoe (or tomol) and new harpoons that provided the opportunity to harvest greater numbers of pelagic or deepwater species, although a few perhaps dated to as early as 5000 years ago have been identified (Harrison and Harrison 1966; Davenport et al. 1993; Bernard 2004; Arnold and Bernard 2005; Rick 2007; Erlandson et al. 2009).

Billfish bones, including the vertebra, rostrum, predentary, and hypural, are often identifiable to species using a reference collection with a range of specimens (Béarez et al. 2016). Moreover, Fierstine (1974, 1990), Gregory and Conrad (1937), and Nakamura (1985) present descriptions of various modern and fossil specimens that can help identify species. However, many archaeological billfish bones are heavily modified vertebrae or fin ray spine fragments that can be difficult to identify to species or even family in some cases (Béarez et al. 2016:188), with some researchers having categories confined to Xiphiidae/Istiophoridae (e.g., Colten 2001: 214, Table 10.9; Rick 2007: 111). This dearth of information can prohibit the understanding of cultural and environmental patterns, such as technological change, food or ritual preference, prehistoric encounter rates, or paleoclimate.

To address this challenge, we performed collagen fingerprinting analysis on 17 modern billfish and tuna specimens, comprising nine species, and then applied these data to 30 archaeological specimens from the Chumash billfish fishery from the Santa Barbara Channel region of southern California (Fig. 1). Collagen fingerprinting (Buckley et al. 2009) or ZooMS (short for Zooarchaeology by Mass Spectrometry; Buckley et al. 2008) is an important and currently under-utilized technique that has been used to address a variety of zooarchaeological questions relating to species identification (e.g., Buckley and Kansa 2011; Buckley et al. 2017a), including the discovery of the remains of extinct species (Buckley et al. 2017b; Hufthammer et al. 2018), but few studies have applied the technique to fish remains (Richter et al. 2011; Harvey et al. 2018). We demonstrate the value of ZooMS for analyzing archaeological fish bones and for addressing questions of broad significance to environmental archaeology and historical ecology, including the ecological versus cultural drivers of the Chumash billfish fishery.

\section{Materials and methods}

Worldwide, billfishes form a separate suborder (Xiphioidei) with two families (Xiphiidae and Istiophoridae) that include swordfishes, marlins, sailfishes, and spearfishes (Nakamura 1985; Collette et al. 2006). The broadbill swordfish (Xiphias gladius) is the only member of the family Xiphiidae. Collette et al. (2006) recognize five genera in the family Istiophoridae, including Makaira (blue marlin), Istiophorus (sailfish), Istiompax (black marlin), Kajikia (striped and white marlin), and Tetrapturus (spearfish). We follow this classification, with all species names conforming to Integrated Taxonomic Information System (ITIS) standards (http://www.itis.gov). Most billfishes inhabit warm tropical waters, with a few species occupying temperate waters as well, including the broadbill swordfish and striped marlin to 50 degrees and 45 degrees north respectively (Nakamura 1985; Shimose et al. 2010).

To cover these various species for our collagen fingerprinting analysis, we obtained 17 modern reference specimens from the Division of Fishes at the Smithsonian's National Museum of Natural History (Table 1). These included three specimens of Xiphias gladius (swordfish; 316704, 316706, and 110042), two Kajikia albida (white marlin; 360507 and 372778), three Kajikia audax (striped marlin; 270773, 270774 and 372777), two Istiophorus platypterus (Indo-Pacific sailfish; 102049 and 109995), and one Makaira nigricans (blue marlin; 196019). In addition to the billfish, we also obtained a few large scombrid specimens, including two Thunnus thynnus (bluefin tuna; 187563 and 268985), three Thunnus alalunga (albacore tuna; 270545, 270550, and 270551), and one Thunnus albacares (yellowfin tuna; 270498) that form an outgroup in our analyses and provide additional data for future large fish collagen fingerprinting. Given that our focus is on the Santa Barbara Channel, two of the most likely species to be identified in our archaeological assemblages are $X$. gladius (broadbill swordfish) and $K$. audax (striped marlin) due to their geographic and temperature limits (Collette and Graves 2019).

To minimize our impact on these specimens, samples were taken from already broken portions of the fish bone or removed from a fin ray spine using a sterile blade. All sampled comparative specimens were dried bone samples prepared by the Smithsonian's Division of Fishes. Specimens were either processed in a dermestid beetle colony or in near-boiling water to remove flesh. They may have been cleaned with ethanol or bleach; these methods of preparation, however, are unlikely to affect the collagen fingerprinting methodology.

In addition to the comparative specimens, we obtained 30 archaeological samples from 12 archaeological sites and four general archaeological localities from the Santa Barbara Channel region of California (Fig. 1, Table 2). These samples were obtained from the Department of Anthropology, Santa Barbara Museum of Natural History and the Department of 


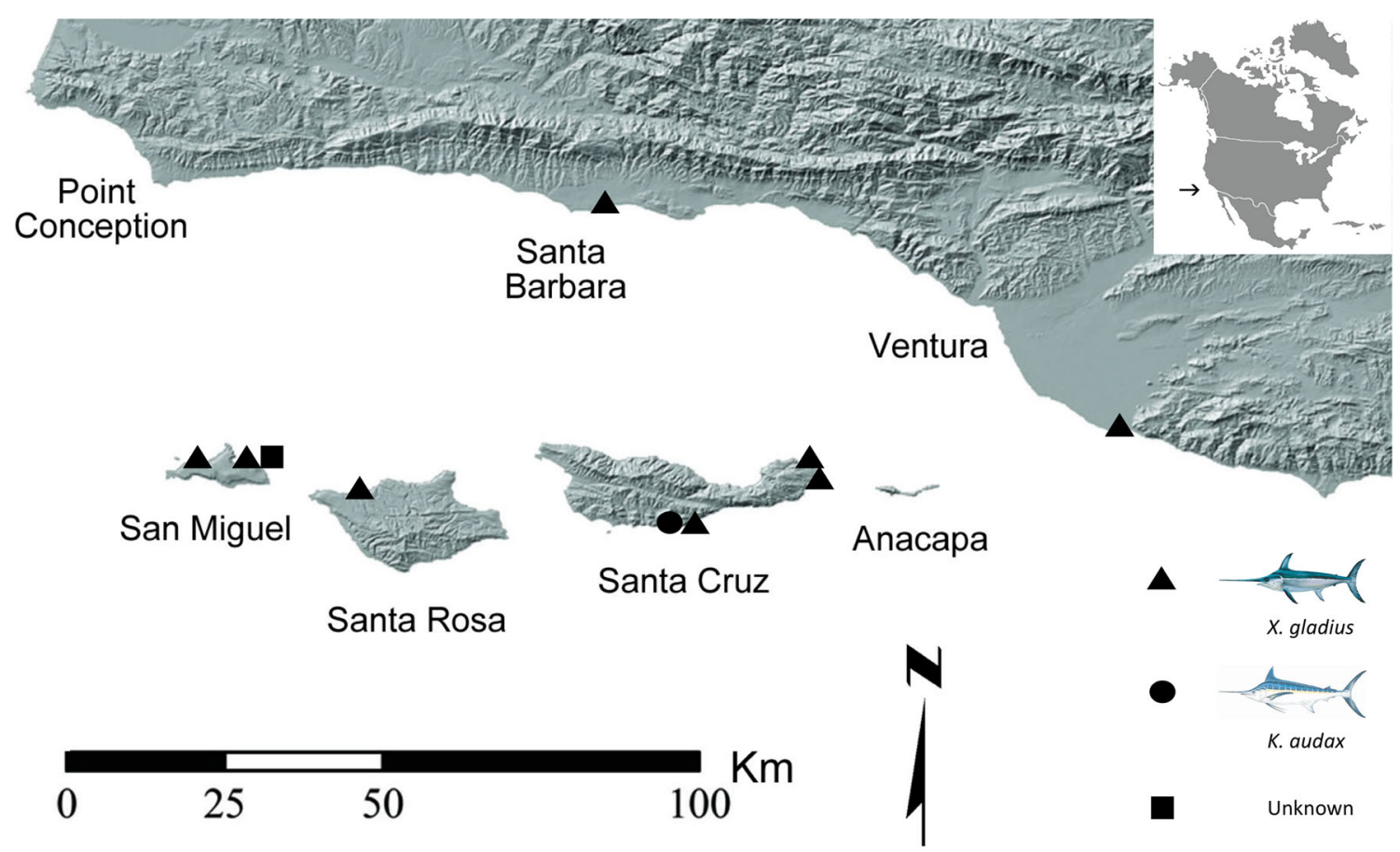

Fig. 1 Location of archaeological sites with swordfish ( $X$. gladius) and striped marlin (K. audax) bones analyzed for this study. Swordfish are marked with a triangle, striped marlin are marked with a circle, and the

Table 1 Modern reference specimens analyzed for collagen fingerprinting from the Division of Fishes, National Museum of Natural History, Smithsonian Institution

\begin{tabular}{ll}
\hline Species & $\begin{array}{l}\text { NMNH Catalog } \\
\text { Number }\end{array}$ \\
\hline Xiphiidae & \\
Xiphias gladius (swordfish) & 316704 \\
X. gladius & 316706 \\
X. gladius & 110042 \\
Istiophoridae & \\
Kajikia albida (white marlin) & 360507 \\
K. albida & 372778 \\
Kajikia audax (striped marlin) & 270773 \\
K. audax & 270774 \\
K. audax & 372777 \\
Istiophorus platypterus (Indo-Pacific & 102049 \\
$\quad$ sailfish) & 109995 \\
I. platypterus & 196019 \\
Makaira nigricans (blue marlin) & \\
Scombridae & 187563 \\
Thunnus thynnus (bluefin tuna) & 268985 \\
T. thynnus & 270545 \\
Thunnus alalunga (albacore) & 270550 \\
T. alalunga & 270551 \\
T. alalunga & 270498 \\
Thunnus albacares (yellowfin tuna) & \\
\hline
\end{tabular}

unknown specimen is marked with a square. All sites are Late Holocene in age and the sites for five failed samples are not listed here

Anthropology, National Museum of Natural History, Smithsonian Institution. Our goal was to minimize the effects on the archaeological specimens so we removed fragments from already broken portions of the bones using sterile blades, including fragments from the rostrum, vertebrae, and fin ray spines (Fig. 2).

Collagen was extracted and digested into peptides following methods described in van der Sluis et al. (2014). In brief, this involved the ultrafiltration of collagen, extracted through incubation of $\sim 50 \mathrm{mg}$ bone powder with $0.6 \mathrm{M}$ hydrochloric acid $(\mathrm{HCl}$; Fisher Scientific, UK) overnight ( $18 \mathrm{~h})$, into $50 \mathrm{mM}$ ammonium bicarbonate (Sigma-Aldrich, UK). One hundred microliters was then digested with $0.4 \mu \mathrm{g}$ sequencing grade trypsin (Promega, UK) overnight and ziptipped with C18 solid-phase extraction pipette tips into $10 \%$ and $50 \%$ acetonitrile $(\mathrm{ACN}) /$ $0.1 \%$ trifluoroacetic acid (TFA). These fractions were then evaporated to completion and resuspended with $10 \mu \mathrm{L} 0.1 \%$ TFA, prior to $1 \mu \mathrm{L}$ being spotted onto a stainless steel matrix-assisted laser desorption ionization (MALDI) target plate with $1 \mu \mathrm{L}$ $10 \mathrm{mg} / \mathrm{mL}$ alpha-cyano hydroxycinnamic acid in 50\% ACN/ $0.1 \%$ TFA. Dried spots were then analyzed using a Bruker Ultraflex II MALDI mass spectrometer collecting up to 2000 laser acquisitions per spot. Samples were then evaporated once more and resuspended with $20 \mu \mathrm{L}$ of $5 \%$ ACN/0.1\% TFA and $2 \mu \mathrm{L}$ analyzed by LC-Orbitrap Elite mass spectrometry in order to assist our understanding of the peptides present. Further sequencing was carried out using an UltiMate ${ }^{\circledR} 3000$ Rapid Separation LC (RSLC, Dionex Corporation, Sunnyvale, CA, 
Table 2 Archaeological billfish specimens, location, element, and collagen-based species identification (excluding five specimens that failed to yield a high quality fingerprint (e.g., Harvey et al. 2016) from the Santa Barbara Mainland (A1208/CA-SBA-73, SBA-28-91/CA-SBA28 and CA-SB-27-11/CA-SBA-27) and San Miguel Island (34176 and 34439 both from CA-SMI-163)

\begin{tabular}{|c|c|c|c|c|c|}
\hline Museum $^{1}$ & Catalog No. & Location & Site & Element & Collagen species ID \\
\hline \multicolumn{6}{|c|}{ Santa Barbara (SB)/Ventura (V) County mainland } \\
\hline NMNH & $26380 \mathrm{a}$ & SB & Unknown & Vertebra & Swordfish (X. gladius) \\
\hline NMNH & $26380 \mathrm{~b}$ & SB & Unknown & Vertebra & Swordfish (X. gladius) \\
\hline $\mathrm{NMNH}$ & $62661 \mathrm{a}$ & SB & CA-SBA-46 (La Patera) & Vertebra & Swordfish (X. gladius) \\
\hline $\mathrm{NMNH}$ & $62661 b$ & SB & CA-SBA-46 (La Patera) & Vertebra & Swordfish (X. gladius) \\
\hline NMNH & $62661 \mathrm{c}$ & SB & CA-SBA-46 (La Patera) & Vertebra & Swordfish $(X$. gladius $)$ \\
\hline $\mathrm{NMNH}$ & $62661 d$ & SB & CA-SBA-46 (La Patera) & Vertebra & Swordfish $(X$. gladius $)$ \\
\hline SBMNH & NA-CA-VEN11-844 & $\mathrm{V}$ & CA-VEN-11 (Muwu) & Rostrum & Swordfish $(X$. gladius $)$ \\
\hline \multicolumn{6}{|c|}{ Northern Channel Islands: Santa Cruz Island (SCI), Santa Rosa Island (SRI), and San Miguel Island (SMI) } \\
\hline $\mathrm{NMNH}$ & 26325 & $\mathrm{SCI}$ & Unknown & Rostrum & Swordfish (X. gladius) \\
\hline NMNH & $26233 \mathrm{a}$ & $\mathrm{SCI}$ & Unknown & Fin ray spine & Swordfish (X. gladius) \\
\hline NMNH & $26233 b$ & $\mathrm{SCI}$ & Unknown & Fin ray spine & Swordfish $(X$. gladius $)$ \\
\hline SBMNH & CHIS-12122 & $\mathrm{SCI}$ & CA-SCRI-423 (Scorpion Ranch) & Rostrum & Swordfish (X. gladius) \\
\hline SBMNH & CHIS-12124 & $\mathrm{SCI}$ & CA-SCRI-423 (Scorpion Ranch) & Vertebra & Swordfish $(X$. gladius $)$ \\
\hline SBMNH & SCRI-496-35 & $\mathrm{SCI}$ & CA-SCRI-496 (Willows) & Predentary & Striped marlin (K. audax) \\
\hline SBMNH & SCRI-496-32 & SCI & CA-SCRI-496 (Willows) & Rostrum & Swordfish $(X$. gladius $)$ \\
\hline SBMNH & CHIS-12522 & $\mathrm{SCI}$ & CA-SCRI-504 (Smugglers Ranch) & Vertebra & Swordfish $(X$. gladius $)$ \\
\hline SBMNH & CHIS-12500 & SCI & CA-SCRI-504 (Smugglers Ranch) & Fin ray spine & Swordfish (X. gladius) \\
\hline NMNH & 23690 & SRI & Unknown & Rostrum & Swordfish $(X$. gladius $)$ \\
\hline SBMNH & 38461 & SRI & CA-SRI-2 & Fin ray spine & Swordfish $(X$. gladius $)$ \\
\hline SBMNH & 38465 & SRI & CA-SRI-2 & Fin ray spine & Swordfish $(X$. gladius $)$ \\
\hline SBMNH & 37792 & SRI & CA-SRI-2 & Fin ray spine & Swordfish (X. gladius) \\
\hline SBMNH & 38951 & SRI & CA-SRI-2 & Vertebra & Swordfish $(X$. gladius) \\
\hline $\mathrm{NMNH}$ & 29664 & SMI & Unknown & Fin ray spine & Swordfish $(X$. gladius $)$ \\
\hline SBMNH & 19617 & SMI & CA-SMI-87 & Vertebra & Swordfish (X. gladius) \\
\hline SBMNH & 34144 & SMI & CA-SMI-163 & Unknown & Unidentified \\
\hline SBMNH & 31769 & SMI & CA-SMI-481 & Vertebra & Swordfish (X. gladius) \\
\hline
\end{tabular}

${ }^{1} N M N H$, National Museum of Natural History; SBMNH, Santa Barbara Museum of Natural History

USA) coupled to an Orbitrap Elite (Thermo Fisher Scientific, Waltham, MA, USA) mass spectrometer (120k resolution, full scan, positive mode, normal mass range 350-1500) following extraction and analysis methods described by Wadsworth and Buckley (2014). In brief, peptides were separated using a gradient from $92 \%$ A $(0.1 \%$ formic acid in water) and $8 \% \mathrm{~B}(0.1 \%$ formic acid in acetonitrile) to $33 \% \mathrm{~B}$ in $44 \mathrm{~min}$ at a flow rate of $300 \mathrm{~nL} \min ^{-1}$ on a $75 \mathrm{~mm} \times 250 \mu \mathrm{m}$ ethylene bridged hybrid (BEH) C18 analytical column (Waters, UK) and automatically selected for fragmentation by data-dependent analysis. Six MS/ MS scans (Velos ion trap, product ion scans, rapid scan rate, centroid data; scan event: 500 count minimum signal threshold, top six) were acquired per cycle employing dynamic exclusion with one repeat scan (i.e., two MS/MS scans total) acquired in a $30 \mathrm{~s}$ duration with that particular precursor excluded for the subsequent $30 \mathrm{~s}$ (activation was by collision-induced dissociation
(CID), 2+ default charge state, $2 \mathrm{~m} / \mathrm{z}$ isolation width, $35 \mathrm{eV}$ normalized collision energy, $10.0 \mathrm{~ms}$ activation time). Peak lists presented as supplementary material are with signal to noise (S:N) cutoff values of 2 (Supplementary Material - Peak Lists). Peptide homology was assisted through error-tolerant searches using Mascot against a modified local database amended by protein BLAST searches of stickleback collagen against marlins.

\section{Results}

\section{Taxonomic resolution within billfish and scombrids}

The striped ( $K$. audax) and white $(K$. albida) marlins share many peptide markers (Fig. 3). However, they can be separated with at least two low-intensity peaks, 
Fig. 2 Archaeological billfish specimens from Santa Rosa Island, California, illustrating rostrum (a), vertebrae (b), and fin ray spines $(\mathbf{c})$. All specimens have evidence of modification including grinding and abrasion

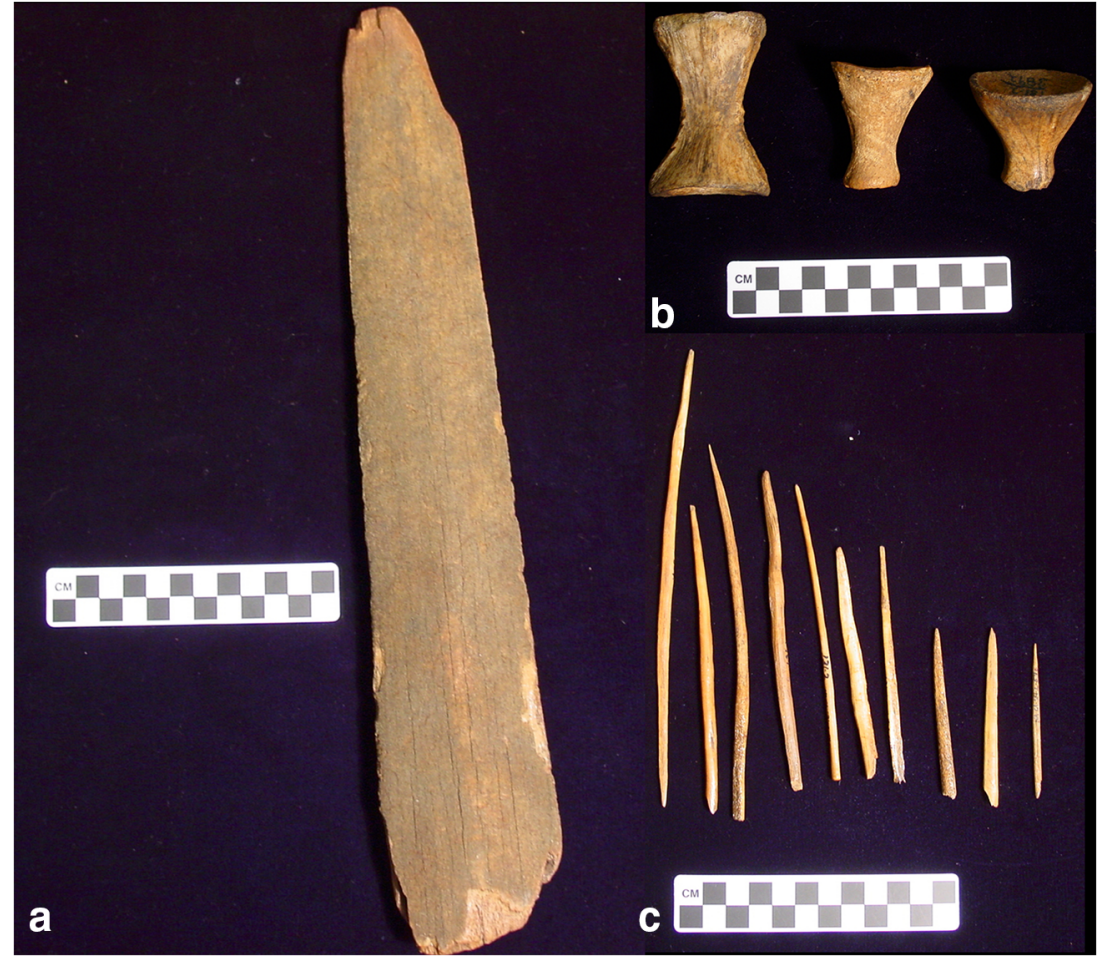

$\mathrm{m} / \mathrm{z}, 1027$ vs 997 and $\mathrm{m} / \mathrm{z}, 2201 / 17$ vs 2213/29 respectively (note that these currently lack sequence confirmation due to poor sequence availability of any closely related fish given the probability-matching nature of this form of "sequencing"). This genus Kajikia is distinct from Makaira and Istiophorus at numerous markers but most confidently at $\mathrm{m} / \mathrm{z}, 1600$ (sequence determination confirms homology with that of $\mathrm{m} / \mathrm{z}, 1596$ in Makaira and Istiophorus; Fig. 3; Supplementary Figures S1-13). Finally, Kajikia is most easily separated from the genus Xiphias at peak $\mathrm{m} / \mathrm{z}, 2454 / 70$ and $\mathrm{m} / \mathrm{z}, 2462$ respectively (Table 3).

The species-level resolution was also observed within the scombrids (Fig. 4). The albacore differs from the other two tunas with $\mathrm{m} / \mathrm{z} 1038$ (vs 1052), whereas separation between the tunas appears possible at $\mathrm{m} / \mathrm{z}$ 2897 in T. thynnus and $\mathrm{m} / \mathrm{z} 2867$ in T. alalunga). The ability to obtain species-level information among the scombrids analyzed here is promising given that most members of this family have relatively recent divergence estimates being within the Pliocene period (Santini et al. 2013; 4 Ma for T. albacares - T. thynnus, but we note the earlier separation of $T$. alalunga at $\sim 8 \mathrm{Ma}$ ), showing improved taxonomic resolution over that of other vertebrates such as mammals (see Buckley 2018 for review). Reassuringly, all of the reference material within any one species tested was identical (e.g., the spectra for the three specimens of $T$. alalunga analyzed had identical peak positions: Supplementary Figure S14).

\section{Species identifications of archaeological billfish from the Santa Barbara Channel}

Of the 25 archaeological specimens that yielded identifiable fingerprints, almost all were found to match those recovered from modern swordfish (Xiphias gladius) collagen. Only two spectra yielded differences with SCRI-496-32, a predentary from Santa Cruz Island apparently most similar to the striped marlin (Kajikia audax; Fig. 5), and 34144, an unidentifiable fragment of bone from San Miguel Island yielding a fingerprint relatively distinct from any of those in the reference material (Supplementary Figure S15).

\section{Discussion and conclusions}

Collagen fingerprinting in billfishes and tunas demonstrates the value of this approach for distinguishing between genera and in some cases between species of these large, pelagic fishes. The approach provides greater confidence in the identification of archaeological billfish remains and can improve issues of zooarchaeological data quality (see Wolverton 2013). Collagen fingerprinting is particularly useful for fragmentary remains that may be difficult or impossible to identify using standard zooarchaeological reference techniques. The reference billfish and tuna spectra provided important markers that help distinguish between Xiphiidae, Istiophoridae, and Scombridae. Other markers appear useful for distinguishing between the istiophorid genera included within this study 


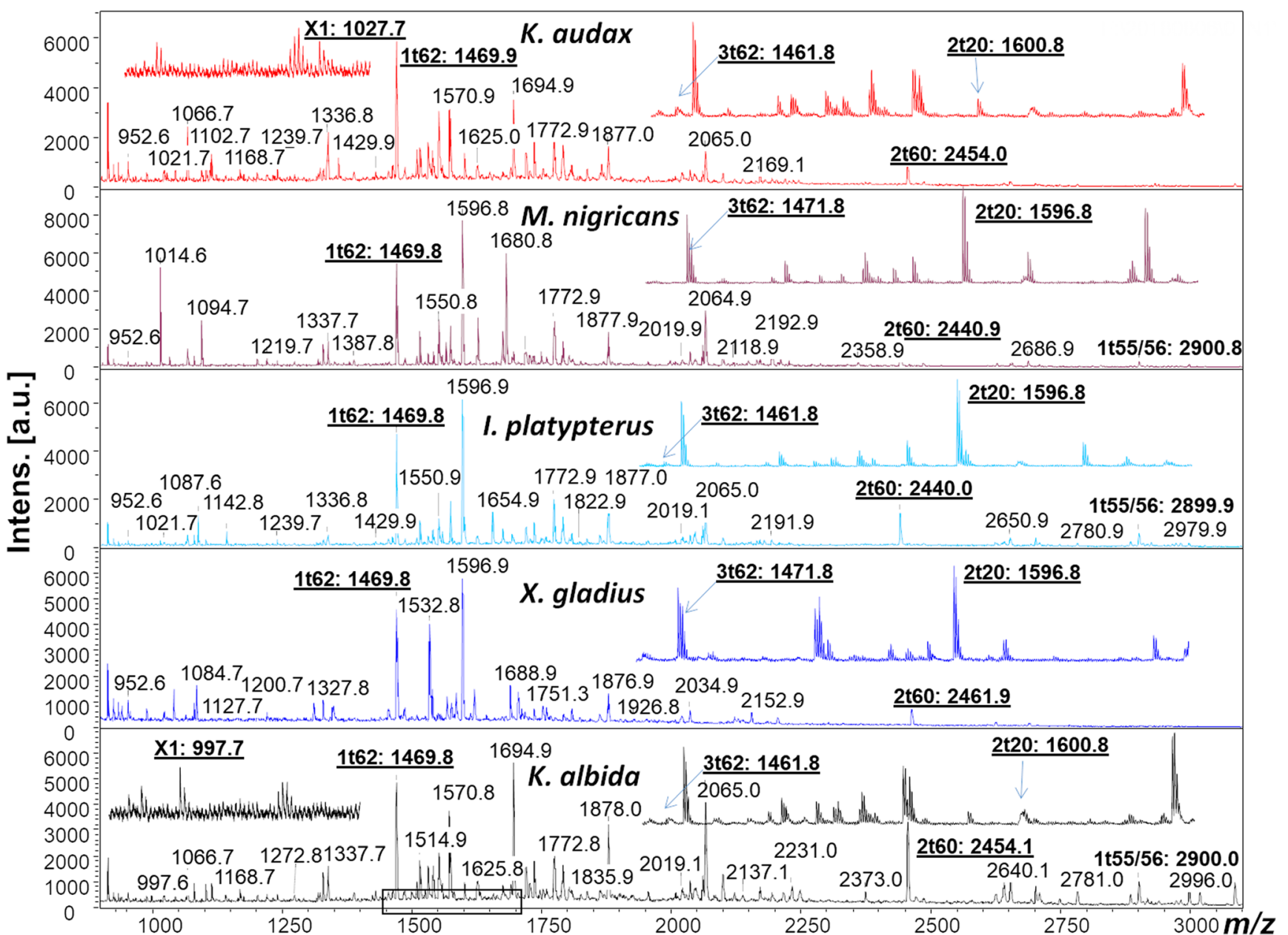

Fig. 3 Peptide mass fingerprints from tryptic digests of collagen showing genus- and species-level distinctions in modern billfish, including Kajikia, Xiphias, Makaira, and Istiophorus. The values on the x-axis represent the mass to charge ratio $(\mathrm{m} / \mathrm{z}$ ) values of the peptides (enzymatic

(Makaira, Istiophorus, and Kajikia), and in some cases also at the species level (e.g., K. audax and K. albida). The ability to separate within the genus level with Kajikia is surprising given that the two species are so closely related that DNA

Table 3 List of key collagen peptide mass biomarkers that separate the modern billfish and tunas analyzed in this study. Confirmation of homology obtained for several peptides can be found in the Supplementary Material, Figures S1-13 (superscripted with relevant fragments) of collagen; it is typically the variations in the amino acids within each peptide that result in the differences in observed; (inset shows zoomed in area from box on the $\mathrm{x}$ - axis of the bottom spectrum)

barcoding was unable to distinguish between them (Hanner et al. 2011), but we note that we were not able to identify the sequence of this proposed biomarker and therefore have as much confidence in their homology as we do for the other biomarkers.

figure number); *1t55/56 biomarker not observed in all archaeological $X$. gladius samples, potentially due to both size and presence of internal tryptic site, but not required for identification

\begin{tabular}{|c|c|c|c|c|c|c|c|c|c|}
\hline Order & Family & Species & $X$ & $3 \mathrm{t} 47$ & $3 t 62$ & $1 \mathrm{t} 62$ & $2 \mathrm{t} 20$ & $2 \mathrm{t} 60$ & $1 t 55 / 56^{*}$ \\
\hline Scombriformes & Scombridae & T. alalunga & & $1038^{\mathrm{S} 1}$ & $1445^{\mathrm{S} 4}$ & $1443^{S 7}$ & $1600^{\mathrm{S} 10}$ & & 2867 \\
\hline Scombriformes & Scombridae & T. thynnus & & $1052^{\mathrm{S} 2}$ & $1445^{\mathrm{S} 4}$ & $1443^{S 7}$ & $1600^{\mathrm{S} 10}$ & & 2897 \\
\hline Scombriformes & Scombridae & T. albacares & & $1052^{\mathrm{S} 2}$ & $1445^{\mathrm{S} 4}$ & $1443^{S 7}$ & $1600^{\mathrm{S} 10}$ & & 2867 \\
\hline Istiophoriformes & Xiphidae & $X$. gladius & & $1084^{\mathrm{S} 3}$ & $1471^{\mathrm{S} 6}$ & $1469^{\mathrm{S} 8}$ & $1596^{\mathrm{S} 9}$ & $2462^{\mathrm{S} 12}$ & 2889 \\
\hline Istiophoriformes & Istiophoridae & K. audax & 1027 & & $1461^{\mathrm{S} 5}$ & $1469^{\mathrm{S} 8}$ & $1600^{\mathrm{S} 10}$ & $2454 / 2470^{\mathrm{S} 11}$ & $2899^{\mathrm{S} 13}$ \\
\hline Istiophoriformes & Istiophoridae & K. albida & 997 & & $1461^{\mathrm{S} 5}$ & $1469^{\mathrm{S} 8}$ & $1600^{\mathrm{S} 10}$ & $2454 / 2470^{\mathrm{S} 11}$ & $2899^{\mathrm{S} 13}$ \\
\hline Istiophoriformes & Istiophoridae & M. nigricans & & & $1471^{\mathrm{s} 6}$ & $1469^{\mathrm{S} 8}$ & $1596^{\mathrm{S} 9}$ & 2440 & $2899^{\mathrm{S} 13}$ \\
\hline Istiophoriformes & Istiophoridae & I. platypterus & & & $1461^{\mathrm{S} 5}$ & $1469^{\mathrm{S} 8}$ & $1596^{\mathrm{S9}}$ & 2440 & $2899^{\mathrm{S} 13}$ \\
\hline
\end{tabular}


This highlights one of the main challenges that clearly remains for ZooMS, in obtaining sequence information for all potential biomarkers given the limitations of "error-tolerant" type searches (able to account for one amino acid substitution or modification per peptide) and difficulties in de novo sequence interpretation, at least until further genetically derived sequences for the relevant collagen genes are obtained for more closely related taxa than currently available.

Several studies have focused on the importance of prehistoric billfish fisheries in southern California, the Gulf of Maine, and northern Chile (Davenport et al. 1993; Spiess and Lewis 2001; Bernard 2004; Sanger 2009; Béarez et al. 2016). These analyses demonstrate that these fishes were being taken offshore, but perhaps near submarine canyons or areas of steep bathymetry that would bring the fishes closer to the coastline where they could be harpooned from a boat. These fisheries were understandably risky and were often parts of ritual systems, as well as for food (see Davenport et al. 1993). The Gulf of Maine fishery appears to have been focused entirely on swordfish ( $X$. gladius; Spiess and Lewis 2001; Bourque 2012). Similarly, linguistic, ethnographic, and archaeological data for the Chumash fishery have focused on
$X$. gladius (Davenport et al. 1993), with researchers also recognizing the possibility of istiophorids but with limited attention given to these species (i.e., K. audax; Colten 2001; Bernard 2004; Rick 2007). The Chilean billfish fishery at the Zapatero site contains a mix of swordfish ( $X$. gladius; $n=23$ ) and striped marlin (K. audax; $n=98)$ remains, with striped marlin dominating. The abundance of these two species is not surprising given that they can at times be found near the surface where they can be more easily harpooned (Béarez et al. 2016; Nakamura 1985; Shimose et al. 2010).

Our collagen fingerprinting of 30 archaeological specimens from throughout the Santa Barbara Channel supports the previous pattern of mostly swordfish remains being uncovered from the Santa Barbara Channel with at least 23 from $X$. gladius and one from $K$. audax. Although analyses of additional specimens may identify more $K$. audax remains, we suspect that the majority of the billfish remains from the area will be $X$. gladius. This is likely due to a combination of factors, pivoting on the potential encounter rates of the two species, but could also possibly relate to food preferences and/ or ritual significance of $X$. gladius (see Davenport et al. 1993). Love (1996) notes that swordfish are found as far north as the

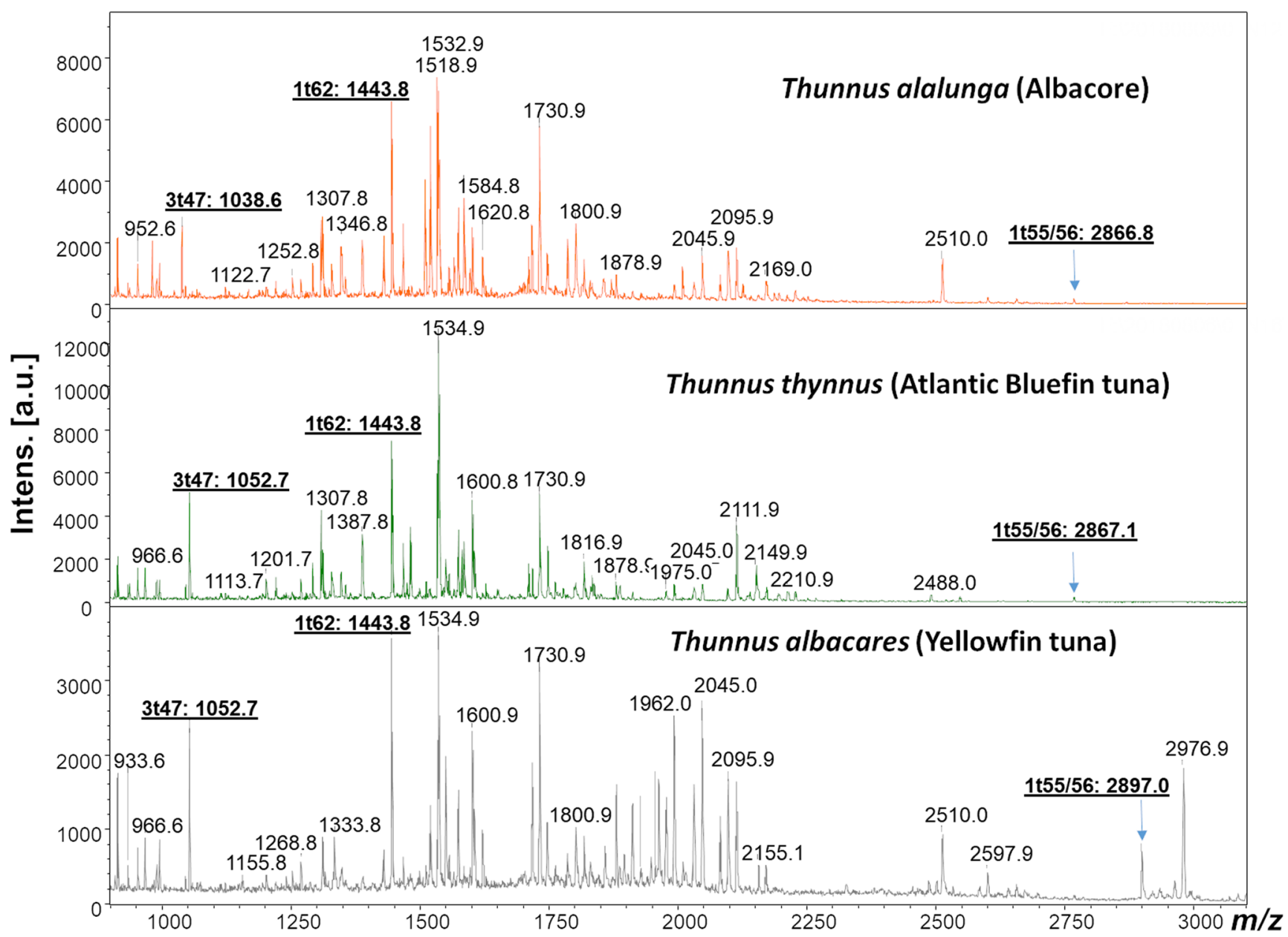

Fig. 4 Peptide mass fingerprints from tryptic digests of collagen showing species-level distinctions in modern tunas (Thunnus spp.) 


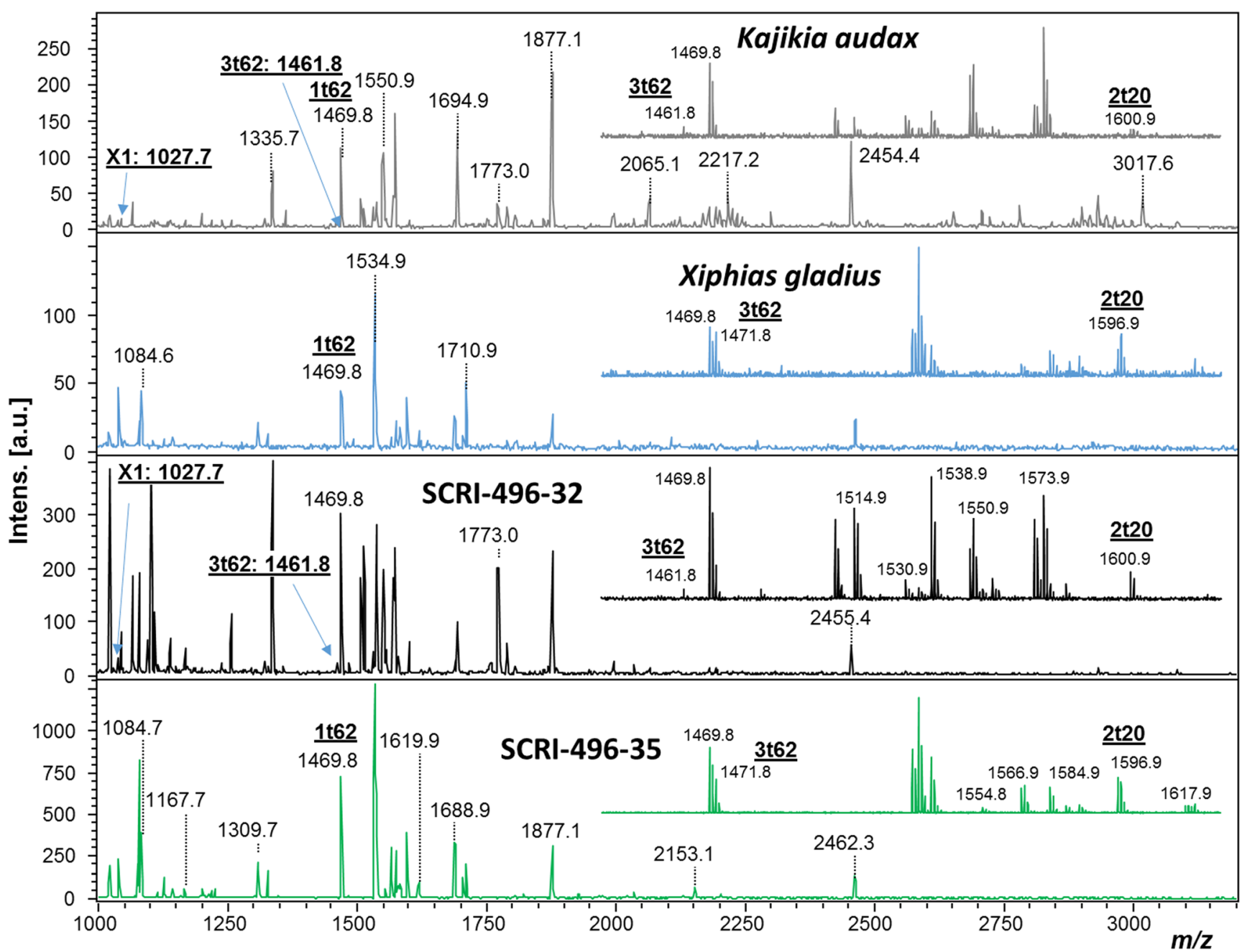

Fig. 5 Peptide mass fingerprints from tryptic digests of collagen showing taxonomic identification of archaeological samples in relation to the two closest matching modern reference spectra

coasts of Vancouver Island, British Columbia, but are most common south of Point Conception. Similarly, striped marlin are known to the coasts of Oregon but are rare north of Santa Barbara Island, which is well south of the Santa Barbara Channel and in warmer waters (see also Bedford and Hagerman 1983). The one K. audax from our study is from CA-SCRI-496, which is located on the south coast of Santa Cruz Island, which is an area of relatively warm sea surface temperatures compared with parts of the Santa Barbara Channel to the north and west (Blanchette et al. 2009). Similarly, Davenport et al. (1993) mention an additional marlin bone from Mugu, near the far eastern end of the Santa Barbara Channel with warmer waters. Additional analyses can help further assess the frequency of swordfish vs. marlin in Santa Barbara Channel and Channel Island sites, particularly analyses of the more limited number of billfish remains from the Southern Channel Islands that may have a higher likelihood of containing $K$. audax due to the warmer waters (Salls 1988). A single sailfish (Istiophorus platypterus) bone was identified at a Late Holocene site on Catalina Island, suggesting the presence of this billfish species in the region as well (Porcasi and Radde 2017).

Collagen fingerprinting has emerged as an important technique for archaeologists and Quaternary scientists, and this molecular tool is particularly useful for zooarchaeological identifications. Although several recent studies have demonstrated the value of this technique, many of these focus on terrestrial (Buckley et al. 2016, 2017) or marine mammals (Buckley et al. 2014; Evans et al. 2016; Hufthammer et al. 2018), with comparatively limited attention, albeit growing, to fishes (Richter et al. 2011; Harvey et al. 2018). Our study is the first to use collagen fingerprinting for species identification of billfish, and points to the potential value of these data for helping understand prehistoric fisher encounter rates with various species and, if combined with archaeological evidence, ritual, and cultural variables. One area that may prove fruitful for future investigation is using collagen fingerprinting on tuna remains to help understand important debates about the nature of tuna fishing in the Caribbean, Indo-Pacific, and beyond. For instance, the debate over the nature of Late 
Pleistocene deep-water fishing in the Indo-Pacific has been hindered by the fact that the specimens were identified to the family-level (Scombridae), with members of this family having variable life history and ecological requirements (see Anderson 2013; O'Connor and Ono 2013). Under this remit, collagen fingerprinting is likely to prove to be an important technique for future research on this and other topics, with the data presented here demonstrating its potential for identifying fish remains and addressing issues of broad significance to archaeology and historical ecology.

Acknowledgments We thank Jeff Clayton, Dave Johnson, Lisa Palmer, and Jeff Williams from the National Museum of Natural History (NMNH), Division of Fishes for providing access to sample the modern reference specimens used in this study. Dave Johnson and Bruce Collette provided important suggestions for our research. We thank Esther Rimer of the NMNH Department of Anthropology for help with the NMNH archaeological samples. At the Department of Anthropology, Santa Barbara Museum of Natural History, Tacy Kennedy and John Johnson provided access to their archaeological specimens.

Funding information This project received financial support from the Royal Society in the form of a University Research Fellowship to MB and the University of Manchester Dean's Award for scholarship funding to $\mathrm{VH}$.

Open Access This article is distributed under the terms of the Creative Commons Attribution 4.0 International License (http:// creativecommons.org/licenses/by/4.0/), which permits unrestricted use, distribution, and reproduction in any medium, provided you give appropriate credit to the original author(s) and the source, provide a link to the Creative Commons license, and indicate if changes were made.

\section{References}

Anderson A (2013) The antiquity of sustained offshore fishing. Antiquity $87: 879-885$

Arnold JE, Bernard J (2005) Negotiating the coasts: status and the evolution of boat technology in California. World Archaeol 37:109-131

Béarez P, Fuentes-Mucherl F, Rebolledo S, Salazar D, Olguín L (2016) Billfish foraging along the northern coast of Chile during the Middle Holocene (7400-5900 cal BP). J Anthropol Archaeol 41:185-195

Bedford DW, Hagerman FB (1983) The billfish fishery resource of the California Current. CalCOFI Rep 24:70-78

Blanchette CA, Raimondi PT, Broitman BR (2009) Spatial patterns of intertidal community structure across the California Channel Islands and links to ocean temperature. In: Damiani CC, Garcelon DK (eds) Proceedings of the seventh California Islands Symposium. Institute for Wildlife Studies, Arcata, CA, pp 161-173

Bourque B (2012) The swordfish hunters: the history and ecology of an ancient American sea people. Bunker Hill Publishing, New Hampshire

Buckley M (2018) Zooarchaeology by mass spectrometry (ZooMS) collagen fingerprinting for the species identification of archaeological bone fragments. In: Giovas C and Lefebvre M (eds) Zooarchaeology in practice. Springer, Cham, pp 227-247

Buckley M, Collins MJ, Thomas-Oates J (2008) A method of isolating the collagen (I) alpha 2 chain carboxytelopeptide for species identification in bone fragments. Anal Biochem 374:325-334
Buckley M, Collins MJ, Thomas-Oates J, Wilson J (2009) Species identification by analysis of bone collagen using matrix-assisted laser desorption/ionisation time-of-flight mass spectrometry. Rapid Commun Mass Spectrom 23:3843-3854

Buckley M, Fraser S, Herman J, Melton ND, Mulville J, Pálsddóttir AH (2014) Species identification of archaeological marine mammals using collagen fingerprinting. J Archaeol Sci 41:631-641

Buckley M, Gu M, Shameer S, Patel S, Chamberlain AT (2016) Highthroughput collagen fingerprinting of intact microfaunal remains; a low-cost method for distinguishing between murine rodent bones. Rapid Commun Mass Spectrom 30:1-8

Buckley M, Harvey V, Chamberlain A (2017) Species identification and decay assessment of Late Pleistocene fragmentary vertebrate remains from Pin Hole Cave (Creswell Crags, UK) using collagen fingerprinting. Boreas 46(3):402-411

Collette B, Graves J (2019) Tunas and billfishes of the world. Johns Hopkins University Press, Baltimore

Collette BB, McDowell JR, Graves JE (2006) Phylogeny of recent billfishes (Xiphioidei). Bull Mar Sci 79:455-468

Colten RH (2001) Ecological and economic analysis of faunal remains from Santa Cruz Island. In: Arnold J (ed) The origins of a Pacific coast chiefdom: the Chumash of the Channel Islands. University of Utah Press, Salt Lake City, pp 199-219

Davenport D, Johnson JR, Timbrook J (1993) The Chumash and the swordfish. Antiquity 67:257-272

Ellis R (2013) Swordfish: a biography of the ocean gladiator. University of Chicago Press, Chicago

Erlandson JM, Rick TC, Braje TJ (2009) Fishing up the food web? 12, 000 years of maritime subsistence and adaptive adjsutments on California's Channel Islands. Pac Sci 63:711-724

Evans S, Briz i Godino I, Alvarez M, Rowsel K, Collier P, Prosser de Goodall RN, Mulville J, Lacrouts A, Collins MJ, Speller C (2016) Using combined biomolecular methods to explore whale exploitation and social aggregation in hunter-gatherer-fisher society in Tierra del Fuego. J Archaeol Sci Rep 6:757-767

Fierstine HL (1974) The paleontology of the billfish - the state of the art. In: Shomura R, Williams F (eds) Proceedings of the international billfish symposium, Kailua Kona, 1972. NOAA Technical Report NMFS SSRF-675, pp 34-44

Fierstine HL (1990) A paleontological review of three billfish families (Istiophoridae, Xiphidae, and Xiphiorhynchidae). In Stroud R (ed) Planning the future of billfishes part 2, proceedings of the second international billfish symposium. Kailua-Kona, 1988, p 11-19

Gregory WK, Conrad GM (1937) The comparative osteology of the swordfish (Xiphias) and the sailfish (Istiophorus). Am Mus Novit 952:1-28

Harvey V, Egerton VM, Chamberlain AT, Manning PL, Buckley M (2016) Collagen Fingerprinting: A New Screening Technique for Radiocarbon Dating Ancient Bone. PLOS ONE 11 (3):e0150650

Harvey VL, Daugnora L, Buckley M (2018) Species identification of ancient Lithuanian fish remains using collagen fingerprinting. J Archaeol Sci 98:102-111

Hildebrandt W, McGuire K (2002) The ascendance of hunting during the California Middle Archaic: an evolutionary perspective. Am Antiq 67:231-256

Hufthammer AK, Arntsen L, Kitchener AC, Buckley M (2018) Grey whale (Eschrichtius robustus) in Norwegian waters 2000 years ago. Palaeogeogr Palaeoclimatol Palaeoecol 495:42-47

Lebow CG, Harro DR, McKim RL (2016) The archaeology and rock art of swordfish cave. University of Utah Anthropological Paper 129. University of Utah Press, Salt Lake City

Love M (1996) Probably more than you want to know about the fishes of the Pacific coast. Really Big Press, Santa Barbara

Mather CO (1976) Billfish: marlin, broadbill, sailfish. Saltaire Publishing, Sydney 
Nakamura I (1985) Billfishes of the world: an annotated and illustrated catalogue of marlins, sailfishes, spearfishes, and swordfishes known to date. FAO Fisheries Synopsis 125, vol 5

O'Connor S, Ono R (2013) The case for complex fishing technologies: a response to Anderson. Antiquity $885-888$

Porcasi J, Radde H (2017) Late Holocene occupational cycles at Toyon Bay, Santa Catalina Island, Alta California. Calif Archaeol 9:21-51

Richter KK, Wilson J, Jones AKG, Buckley M, van Doorn N, Collins MJ (2011) Fish 'n chips: ZooMS peptide mass fingerprinting in a 96 well plate format to identify fish bone fragments. J Archaeol Sci 38: $1502-1510$

Rick TC (2007) The archaeology and historical ecology of Late Holocene San Miguel Island. Cotsen Institute of Archaeology, University of California, Los Angeles

Salls R (1988) Prehistoric fisheries of the California Bight. PhD Dissertation, University of California, Los Angeles

Sanger D (2009) Foraging for swordfish (Xiphias gladius) in the Gulf of Maine. In: Keenlyside D, Pilon J (eds) Painting with a broad brush: papers in honor of James V. Wright. National Museum of Civilization, Quebec, pp 1-36

Shimose T, Yokawa K, Saito H (2010) Habitat and partitioning of billfishes (Xiphioidei). J Fish Biol 76:2418-2433

van der Sluis LG, Hollund HI, Buckley M, De Louwd PGB, Rijsdijke KF, Kars H (2014) Combining histology, stable isotope analysis and ZooMS collagen fingerprinting to investigate the taphonomic history and dietary behaviour of extinct giant tortoises from the Mare aux Songes deposit on Mauritius. Palaeogeogr Palaeoclimatol Palaeoecol 416:80-91

Wolverton S (2013) Data quality in zooarchaeological faunal identification. J Archaeol Method Th 20:381-396

Publisher's note Springer Nature remains neutral with regard to jurisdictional claims in published maps and institutional affiliations. 